\title{
THE EFFECT OF WORKLOAD AND WORK ENVIRONMENT ON JOB STRESS AND ITS IMPACT ON THE PERFORMANCE OF NURSE INPATIENT ROOMS AT MATARAM CITY GENERAL HOSPITAL
}

\author{
Afrina Susiarty \\ Faculty of Economics and Business \\ Mataram University \\ Mataram, Indonesia \\ afrinasusi80@gmail.com \\ Lalu Suparman \\ Faculty of Economics and Business \\ Mataram University \\ Mataram, Indonesia \\ lalusuparman77@gmail.com \\ Mukmin Suryatni \\ Faculty of Economics and Business \\ Mataram University \\ Mataram, Indonesia \\ msuryatni@yahoo.com
}

DOI: 10.31364/SCIRJ/v7.i6.2019.P0619661

http://dx.doi.org/10.31364/SCIRJ/v7.i6.2019.P0619661

\begin{abstract}
The purpose of this research as follows to examine and analyze the effect of workload and work environment on job stress and its impact on the performance of nurse inpatient rooms at Mataram city general hospital. This type of research is kusal. Respondents were all employees whose status as a nurse on the inpatient unit Mataram City Regional Hospital as many as 128 nurses. Data collection used by questionnaires. Data analysis and hypothesis testing is done with the approach of this study Partial Least Square (PLS) using software SmartPLSversi 3.0. The results showed that (1) Workload has a positive and significant impact on Job Stress. (2) Working Environment has a negative and significant impact on Job Stress. (3) Workload has a negative effect but no significant effect on performance. (4) Working Environment has a positive and significant impact on performance. (5) Work Stress has a negative and significant impact on performance.
\end{abstract}

Index Terms- Workload, Job Stress, Work Environment, Performance

\section{INTRODUCTION}

Health services included in the service industry and the primary health plays an important role. The hospital is one form of organization in the health services industry engaged in health care, where one of the efforts is to support a referral of a basic level of services, such as health centers. In accordance with Act No. 44 of 2009 the definition of a hospital that health care institution that organizes personal health services in plenary that provides inpatient, outpatient, and emergency services. Health care provided hospital must be qualified, effective and efficient, supported by the quality and quantity of energy.

The nurse is one of the components that have an important role in providing health care in a hospital farther nurse is a medical staff that has the highest 
intensity of interaction with patients and families in providing health services. Nurses are required to maintain the quality and professionalism in providing services to patients. Always improve performance and productivity and show hospitality to each patient and family. Because the performance of nurses continues to be a concern of various parties. Performance of a nurse can be seen from the quality of nursing care provided to patients. Quality nursing care results-oriented baiik patients.

The workload affects the stress levels of nurses. According Manuaba (2013), the workload can be a task or job demands, organization and work environment. Workload of nurses in hospitals include physical and mental workload. Physical workload of nurses include lift patients, bathing patients, helping patients to the bathroom, pushing medical equipment, making the beds of patients, encouraging patients brankart. The burden of mental work can be a work shift system, maintain good communication with other nurses, employers, patients and families of patients, prepare spiritually mental patients and families, especially for those who will carry out the operation or in critical condition, working with specialized skills and responsibilities towards the patient's recovery.

Workload of nurses in hospitals Kota Mataram increased by accompanying physician visits to patients and their administrative work is complete the administrative discharge of patients in each ward is still done by nurses because there is no clerk on inpatient room shift on the day and night as well as holidays. All of that is actually not the main task of the nurses, who are inevitably still be the main task of nursing so that nurses are not optimal performance. With the additional nonnursing tasks impact the increased workload of nurses non-nursing is one cause of the neglect of the main tasks of patient-oriented nursing. Reduced time nurses to interact with patients and perform nursing care.

Several previous studies showing the effect of workload with stress of work, such as research conducted by Krantz \& Lundberg (2016) on workers in Sweden showed that workload positive effect on job stress. This study was supported by research conducted by Nova Ellyzar, Yunus and Amri (2017) at Aceh province BPK employees and research conducted by Denizia Rizky and Tri Wulida Afrianty (2018) on the Social Service of East Java Province.

Instead some previous studies also showed no significant influence of the workload with job stress as research conducted by Kurnia (2012) showed that there was no physical workload relationship with work stress on hospital emergency nurses Cianjur. This study was supported by research conducted by Yada (2015) on a psychiatric nurse and research Fitr (2013) found that there was no relationship between mental work load with work stress.

Research Ahmad and Afgan (2016) states that occupational stress occurs in a company with a significant negative effect employee performance, in the sense that if an employee experiencing job stress, the performance will be achieved decreases. A similar sentiment was also expressed in the researchAlkubaisi, M., (2015)stating the results show that the stress of work and the performance had a negative impact. But not forever work stress a significant negative effect on performance.

Previous research suggests that, positive berepngaruh work stress on employee performance. This is shown in researchLankeshwara (2016) which states that the positive effect of work stress on employee performance. The study was supported by researchPrihartini (2017) which states that work-related stress positive and significant impact on performance.

The purpose of the study as follows:

1) To test and analyze the effect of workload on nurses job stress inpatient room Mataram City Regional Hospital.

2) To test and analyze the effect of work stress work environment on inpatient room nurse Mataram City Regional Hospital.

3) To test and analyze the effect of workload on the performance of nurse patient room Mataram City Regional Hospital.

4) To test and analyze the influence of the working environment on the performance of nurse patient room Mataram City Regional Hospital.

5) To test and analyze the effect of work stress on performance inpatient room nurse Mataram City Regional Hospital.

\section{LITERATURE REVIEW}

\section{A. Workload}

Everly and Girdano (1980) in Sunyoto (2011)said that the workload is a situation where workers faced with the task to be completed at a specific time. Another category of workload is a combination of quantitative and qualitative workload. Quantitative workload arising from the tasks are too many or few, whereas qualitative workload if workers feel unable to perform a task or tasks do not use the skills or the potential of workers.

According Meshkati in Tarwaka et al (2015), the work load is defined as a difference between the capacity or the ability of workers to the demands of the job that must be addressed considering human labor is physical and mental, then each has a loading level different. The loading level is too high allowing excessive energy consumption and occurs overstres, otherwise encumbering too low intensity allows a sense of burden and boredom. Therefore it is necessary that the optimum loading level of intensity that exist between these two extreme limits before and certainly different between individuals with each other.

According to Hart and Staveland in Tarwaka et al (2015), that the workload is something that arises from the interaction between the demands of the tasks, the 
working environment which is used as a workplace, skills, attitudes and perceptions of workers. Workload is sometimes also be defined operationally on various factors such as the task demands or efforts are being made to do the job. Therefore, not only considering the workload or one aspect, as long as other factors have interaction in complex ways.

In this study workload indicators used adopting of Manuaba (2013) as follows:
a. The complexity of the job
b. Job volume
c. Type of work
d. The level of difficulty of the job
e. Job responsibilities
f. time to work
g. Delegation of tasks and responsibilities

\section{B. Work environment}

The working environment in the citation Indarti et al. (2014) are factors outside of humans in the form of physical and non-physical within an organization and gives the impression of a pleasant, securing, reassuring and feel at home working According Sedarmayanti (2013) working conditions said to be good or as if a human can undertake an optimal, healthy, safe and comfortable. Suitability working environment can be seen as a result in a longer period of time further work environments are less well able to sue labor and more time and does not support obtaining an efficient work system design. As according Susilo (2012) work environment, among others:

a. Fellow labor environment

Susana is created by the interaction with a fellow worker.

b. With a superior working environment

Namely the working atmosphere is created by the interaction between employees and employers, as well as machinery and equipment environment.

c. Environmental machinery and equipment

Environment faced by employees, which enables employees do not concentrate on the job.

The work environment indicators used in this study is adopted from Sedarmayanti (2013) as follows:

a. Physical Work Environment

- The availability of facilities and infrastructure

- The facilities were good

- The availability of adequate equipment and complete

b. Non Physical Environment

- Your organization's policy

- Attention leader / supervisor

- Support colleagues

- The demands of patients and families

\section{Work stress}

Work stress is a response to a person's shape, both physically and mentally to a changing environment is felt intrusive and resulted in his being threatened.
Every aspect dipekerjaan plant can be stressful. Labor that determines the extent to which the situation facing a stressful situation or not. Labor in its interaction at work, influenced by the result of the interaction in other places, in ruamh, at school, in clubs and so on (Sunyoto, 2015).

According to Griffin (2012) states that there are four causes of workplace stress is as follows:

a. The physical environment

The cause of work stress on the physical environment in the form of light, sound, temperature and the air is polluted.

b. Individual

Individual pressure as the cause of the stress of work consists of:

1. role conflict

2. Double role

3. Excessive workload

4. The absence of control

5. Responsible

6. working conditions

c. Group

The effectiveness of any organization is influenced by the nature of the relationship between the groups. Characteristics of the group into a strong stressor for some individuals. Workers' distrust of partners is positively related to high double role, which carries on the communication gap between people and low job satisfaction. Or in other words their poor relationship with colleagues, superiors and subordinates.

d. organizational

Their organizational structure design is ugly, ugly politics and the absence of specific policies.

\section{Performance}

Performance in an organization can be used as a reference organization's success or failure in achieving the goals set. Chandra \& Priyono (2016) describe kinerja as the ability of individuals in reaching requirements of the job with indicators of loyalty, achievement, responsibility, work, honesty, obedience. While Mangkunagara (2016) performance (performance) is the result of the quality and quantity of work achieved an employee in performing their duties in accordance with the responsibilities given to him.

The dimensions of performance is the size and ratings of behavior in the workplace including the quality and quantity of output, work hours, until relations of cooperation coworkers (Indarti et al., 2014). In organizations, especially profit-oriented, performance is considered the most important role in generating sustainable profits (Hamid \& Hassan, 2015). It could be argued that the employee's performance is determined when working with consideration of factors such as time management, leadership skills and productivity to assess each employee individually.

Mathis \& Jackson (2016) divides the performance indicators as follows: 
a. Quantity, measured from employees' perception of the amount of activity that are assigned and results.

b. Quality, measured from employees' perception of the quality of work produced and perfection of skills and abilities duties towards employees.

c. Punctuality, measured from employees' perception of a completed activity from the beginning of time into output.

d. Effectiveness, maximum utilization of resources and time available to the organization to increase profits and reduce losses.

e. Presence, this level can determine the performance of employees within a company.

\section{E. CONCEPT FRAMEWORK}

The conceptual framework of research can be said as well as a relationship or link between one of the other concepts of problem you want investigated and allows you to connect or explain a topic to be discussed. The conceptual framework of research in full as follows:

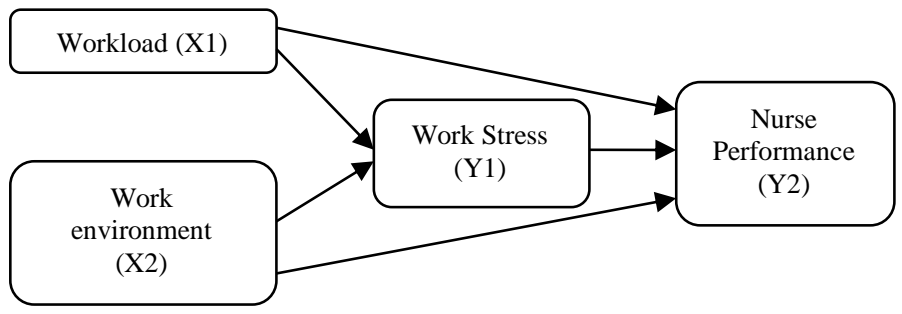

Figure 1. Concept Framework Research

\section{RESEARCH METHODS}

This type of research is a causal aosiatif research. According Sugiyono (2014) associative problem formulation is a formulation of research problems that are to question the relationship between two or more variables. The shape of the causal relationship is a relationship that is both cause and effect. Data collection method used in this research is census. Census method is a data collection diselediki population if all elements one by one. The data obtained are the result of census processing is referred to as the actual data (true value), or often called parameters.

population in this study were all employees whose status as a nurse on the inpatient unit Mataram City Regional Hospital. Number of members of the population that is as much as 128 nurses. All members of the population as respondents in this study. Questionnaire as a tool or instrument of data collection

Data analysis and hypothesis testing is done with the approach of this study Partial Least Square (PLS) using SmartPLS software version 2.0. PLS is a structural equation modeling (SEM) based component or a variant (variance). According Ghozali (2012) PLS is an alternative approach that shifts a covariance-based SEM approaches be based variants. Covariance-based SEM generally examine causality or theory while PLS is more predictive models.

\section{RESULT AND DISCUSSION}

The workload felt by the nurse inpatient room still depends on the category of moderate workload. This shows that all activities that must be carried out in a certain period of time as part of the nursing assignment at the Mataram Regional General Hospital are still dependent on moderate and not excessive workloads. Work Environment that is accepted by the Nursing Room Nurse in the category of a good Work Environment. The Mataram Regional General Hospital, both physical and non-physical, directly or indirectly produces good results for oneself. Job Stress received by the Nurse inpatient room is still in the category of moderate work stress. This means that the feeling of distress experienced by nurses in the work done at the Mataram Regional General Hospital is still at a moderate level. Normal they can still work normally and not too depressed both psychologically and physiologically. Nursing Room Nursing Application by superiors has a good performance at work. This shows that the Inpatient Nurse has good and quality work results that are in accordance with their duties in accordance with the responsibilities given to the Regional General Hospital of the City of Mataram.

To determine the level of significance of the path coefficient, is produced by running a bootstrapping algorithm is used to determine whether the hypothesis is accepted. At the 0.05 level of significance, the hypothesis would be supported if the significance value below the value of 0.05 . The test results can be seen in the level of significance tgambar below.

Results significance smartPLS output image can be seen below,

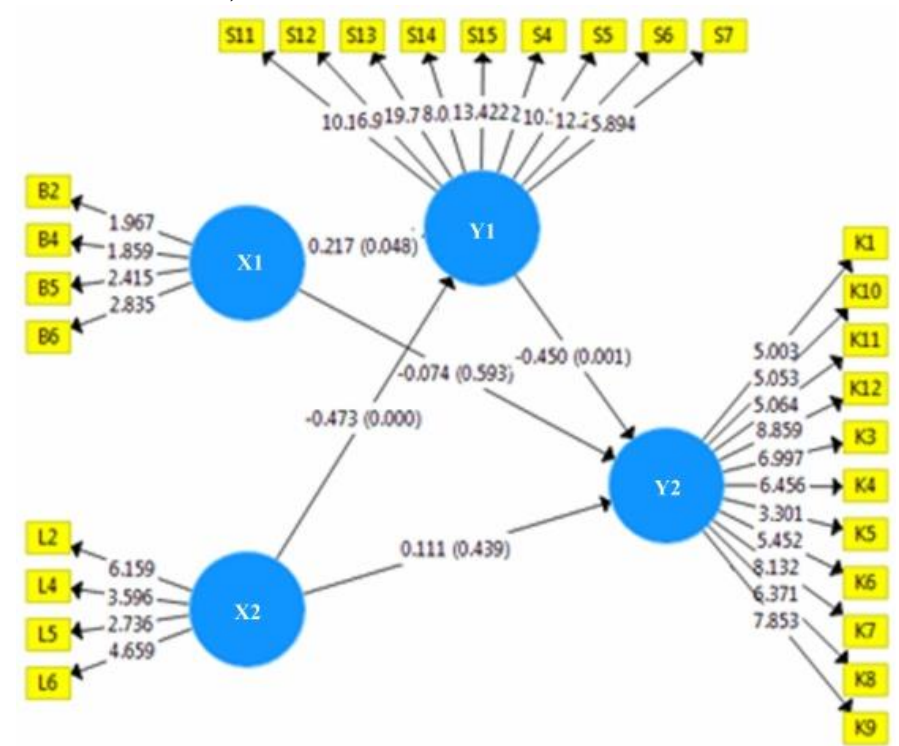

Figure 2. Test Results bootstrapping In SmartPLS

Based on the above tables and figures can be seen that: 
1) Workload have a positive influence on Nurses Job Stress Nurses General Hospital Mataram City 0.217 with a significance level of 0.048 .

2) Work environmenthave a negative effect on Nurses Job Stress Nurses General Hospital Mataram City of -0.473 with a significance level of 0.000 .

3) Workload have a negative effect on the performance of Nurses General Hospital Mataram City of -0.074 with a significance level of 0.593 .

4) Work environment have a positive influence on the performance of Nurses General Hospital Mataram City of 0.111 with a significance level of 0.439 .

5) Work stress has a negative effect on the performance of Nurses General Hospital Mataram City of -0.450 with a significance level of 0.001 .

\section{A. The Effect of Workload on Job Stress}

The results showed that Workloadpositive and significant impact on Nurses Job Stress patient wards at the General Hospital of City of Mataram. Workload higher work performed by nurse patient wards will be coupled with the higher level of Job Stress perceived by the nurse. Conversely, the smaller workload assigned to the nurse will be followed by increasingly low levels of perceived employee Job Stress.

These findings are in line with the concept of the theory proposed by Manuaba in Irvianti and Verina (2015) states that, the workload too much will result in impacts that are not well, that will lead to fatigue both physically and mentally and reaction-emotional reactions such as headaches, indigestion and irritable. It is bad for the smooth working of the organization due to the stress levels of nurses that can affect the overall performance of the organization.

This finding is reinforced by the results of research conducted by Kusuma \& Soesatyo (2014) with the result that the workload of positive and significant effect on employee stress. This study reinforced by Endah (2018) investigated the effect of work stress workload on nurses in inpatient hospital Siti Aisyah Islam Madiun, the results showed that there is the effect of workload on nurses job stress.

Research conducted by Wibowo (2012) showed that workload positive effect on stress. According to research conducted by the Nurses Association of Indonesia (2006) nurses experiencing job stress expressed complaints often feel dizzy, tired, no breaks, among other things because the workload is too high and time-consuming job.

\section{B. The Effect of Work Environment on Job Stress}

The results showed that Workloadpositive and significant impact on Nurses Job Stress patient wards at the General Hospital of City of Mataram. Workload higher the work performed by the nurse will be coupled with the higher level of Job Stress perceived by the nurse. Conversely, the smaller workload assigned to the nurse will be followed by increasingly low levels of perceived employee Job Stress.

This finding is consistent with the theory put forward by Hodson (2012) which says that social support from the workplace can make a contribution, especially on productivity and employee welfare. The creation of a comfortable working environment will reduce the level of stress on the nurses, it is very necessary for a conducive environment that nurses work stress remains at a low level.

Rizki et al (2016) found that the partial work environment has a negative effect, meaning that the better the work environment can reduce stress levels of employees. This finding is also confirmed by research Handoyo (2018), stating that the working environment negatively affect work stress.

Juwita et al (2008) conducted a study that found that the environment or the working conditions greatly affect the comfort of employees, working conditions that do not support would potentially lead to nurses easily fall ill, easily stressed, difficulty concentrating, and lowering produktifiatas performance.

\section{The Effect of Workload on Nurses Performance}

The results showed that Workloadpositive and significant effect on Job Stress at Regional General Hospital Mataram. Workload higher the work performed by the nurse will be coupled with the higher level of Job Stress perceived by the nurse. Conversely, the smaller workload assigned to the nurse will be followed by increasingly low levels of perceived employee Job Stress.

This finding is consistent with the concept of the theory proposed by Winaya (2014) The negative impact of excess workload is a workload that does not comply with labor ability may have negative impacts for employees. The negative impact is decreased work quality. The workload is too heavy is not matched by the ability of the workforce, work overload will result in reduced quality of work as a result of physical fatigue and decrease in concentration, self control, accuracy of work so that the work does not conform to the standard.

The results of this study is slightly different from the results of Andriani and Soesatyo (2014) that the workload and performance of significant negative effect, Chandra and Adriansyahi (2017) found that the work load significantly influence the performance of employees at PT. Mega Auto Central Finance Branch Langsa. Hastutiningsih (2018) found that the work load significantly influence performance. Prihartini (2017) Workload positive effect on performance and are significant.

Meanwhile, this study confirms the results of Fahreza (2017) obtained results of the analysis indicate that the workload is having influence negatively on the performance of employees and Nugraheni (2017) obtained results of the analysis showed that the increased 
workload but no significant impact on the performance of human resources (SDM).

\section{The Effect of Work Environment on Nurses Performance}

The results showed that Workloadpositive and significant effect on Job Stress at Regional General Hospital Mataram. Workload higher the work performed by the nurse will be coupled with the higher level of Job Stress perceived by the nurse. Conversely, the smaller workload assigned to the nurse will be followed by increasingly low levels of perceived employee Job Stress.

This finding is consistent with the concepts put forward by Sedarmayanti (2013) is said to be a good working environment or as if a human can undertake an optimal, healthy, safe and comfortable. Suitability working environment can be seen as a result in a longer period of time further work environments are less well able to sue labor and more time and does not support obtaining an efficient work system design.

The results of this study is slightly different from the results of Hastutiningsih (2018) that the working environment have a significant effect on performance. Tjiabrata et al (2017) there is influence between the work environment on employee performance. Prihartini (2017) obtained results of the analysis showed that non-physical work environment does not affect the performance.

\section{E. The Effect of Job Stress on Nurses Performance}

The results showed that Workloadpositive and significant effect on Job Stress at Regional General Hospital Mataram. Workload higher the work performed by the nurse will be coupled with the higher level of Job Stress perceived by the nurse. Conversely, the smaller workload assigned to the nurse will be followed by increasingly low levels of perceived employee Job Stress.

The findings in this study is corroborated by research Faudin, Sungkawati \& Sumiadji (2015) stated that work stress have a significant effect on the performance of, any increase in work stress will degrade the performance of nurses by $28 \%$. When work stress experienced by employees is too large then the performance will begin to decline, due to the stress interfere with the implementation of the employee. The most extreme consequence is the performance becomes zero, impaired employee, became ill, no longer strong enough to work, become desperate, out or refuse work (Luthfan Atmaji, 2011).

Chandra (2012) partial work stress has a negative and significant effect on the performance of the employee, Akbar (2018) found the work stress has a significantly negative effect on performance.

\section{CONCLUSIONS}

From the research and wording above, the conclusions of the research that can be taken are:
(1) Workloadhas a positive and significant impact on Nurses Job Stress patient wards of the General Hospital of City of Mataram. Workload perceived nurse at the General Hospital of City of Mataram can increase stress at work.

(2) Work environmenthas a negative and significant impact on Nurses Job Stress patient wards of the General Hospital of City of Mataram. Working conducive environment can significantly impact on reduction of perceived stress levels of nurses in the work.

(3) Workloadhave a negative effect but not significant to the performance space Inpatient Nurse Regional General Hospital Mataram. Workload perceived Nurses can degrade the performance of their work. Workload they feel for this is still at a moderate so as not to significantly degrade performance.

(4) Work environment has a positive and significant impact on patient wards Nurse Performance Regional General Hospital Mataram. Working conducive environment will effect an increase in the performance of individuals that will ultimately improve organizational performance.

(5) Job Stress has negative and significant impact on patient wards Nurse Performance Regional General Hospital Mataram. work stress has been perceived by nurses despite the moderate level but it will greatly affect their performance in the Hospital.

Management Regional General Hospital Kota Mataram was very attentive to the workload of nurses, workload given in accordance with the physical capacity as well as knowledge and expertise. Although there are still some workloads that are not in accordance with jobdesk nurses, but nurses have always shown good performance. According Munandar (2001), each one receives workload should be appropriate and balanced well against the physical ability, cognitive ability and the limitations of human receive the load, because the higher the workload to be done, then the stress of work will increase. Based on this, it is important for management to continue to determine the quantity of the workload of nurses in hospitals Mataram.

Hospital Management standard operating procedures should create a better and more standardized associated jobs should be done by nurses so that the work load they are carrying no terlampui at the level of excessive workload. Standard perasional such procedures must be paired with a clearer picture of the job for any nurse who makes them have more knowledge about his work. Each nursing staff who know exactly what they have to do according to their clinical duties and authorities will make the nurse can maintain or improve performance in the delivery of nursing services.

Hospital management should be able to maintain the condition of the working environment. Creating a work environment that does not trigger the nurse work stress 
through increased social support, motivate nurses, provide adequate facilities in accordance with service standards, reward, and improve human resources through training and education.

\section{REFERENCES}

Abdullah, Wahidah., And Utomo, Trianto., (2015), Effects of Workload and Stress at Work Against Employee At PT. PLN (Persero) Region South Sulawesi and West-East Power Sector Power Center Bakaru Bakaru, Abstract available in http://journal.uinalauddin.ac.id/index.php/minds/article/view/462 9

Ahmad, A \& Afgan, S., (2016). The Relationship of Job Stress and Turnover Intention in Commercial Banks of Pakistan by Assessing the mediating Role of Burnout. Journal of Business Strategies. Vol.10, No.1, PP. 1-23.

Alkubaisi, M., (2015). How can Stress Affect Your Work Performance? Quantitative Field Study on Qatari Banking Sector. Business and Management Research. Vol. 4, No. 1, PP: 99-109. ISSN $1927-$ 6001.

Chandra, T \& Priyono., (2016). The Influence of Leadership Styles, Work Environment and Job Satisfaction of Employee Performance - Studies in the School of SMPN 10 Surabaya. International Education Studies. Vol. 9, No. 1, PP. 131-140. ISSN 1913-9020.

Ghozali, Imam. (2012). Applications Multivariate Analysis with SPSS Program. Semarang: Diponegoro University Publishers Agency.

Hamid, NZ A \& Hassan, N., (2015). The Relationship Between Workplace Environment and Job Performance in Selected Government Offices In Shah Alam, Selangor. International Review of Management and Business Research. Vol. 4, No. 3, PP. 845-851. ISSN: 2306-9007.

Haryanti., Aini. F \& Purwaningsih, P., (2013). Relationship Between Workloads With Job Stress nurse in the ER Hospital Semarang regency. Journal of Nursing Management. Vol. 1, No. 1, PP. 48-56.

Indarti, P., Hendriani. S \& Mahda. M., (2014). Influence of Personality Factor Against Employees and Working Environment Employee Performance In Pekanbaru BKN Regional Office XII. Economic Journal. Vol. 22, No. 1, PP. 1-16.
Irvianti, LS D \& Verina, RE, (2015). Analysis of Effect of Job Stress, Workload and Work Environment Against Employee Turnover Intention in PT. XL Axiata Tbk Jakarta. Inktomi Business Review. Vol. 6 No. 1, PP. 117-126.

Kasmarani, MK, (2012). Influence of Physical and Mental Workload Against Nurses Job Stress In Emergency Room (ER) Hospital Cianjur. Journal of Public Health. Vol. 1, No. 2, PP. 767-776.

Krantz, G \& Lundberg, U., (2016). Workload, Work Stress, And Sickness Absence In Swedish Male and Female White-Collar Employees. Scandinavian Journal of Public Health. No. 34, PP. 238-246. ISSN 1403-4948.

Kurniawan, I., (2017). Analysis of Effect of Job Stress, and Work Environment on Employee Performance Workload (Case Study on Employee PT. Sinar Sosro Sales Office Yogyakarta). Journal of PGRI University of Yogyakarta. PP: 1-20.

Lankeshwara, P., (2016). $\quad$ A Study On The Impact Of Workplace Environment OnEmployee's Performance: With Reference To The Brandix Intimate Apparel-Awissawella. International Journal of Multidisciplinary Studies. Vol. 3, No. 1, PP. 47-57.

Mangkunagara, AP, (2016). Performance Evaluation of Human Resources. Bandung: Publisher Refika Aditama

Manuaba, (2013). Workload and Capacity Relationships Work. Jakarta: Rineka Reserved.

Mathis, R. L \& Jackson, JH, (2016). Human Resource Management. Translation.

Jakarta: Four Salemba.

Prihatini, LD (2007). Workload Analysis Relationship With Work Stress Nurses Each patient wards of hospitals Sidikalang, Thesis. University of North Sumatra, Medan. Taken from e-Repository http://repository.usu.ac.id.

Prihartini, U., 2017, Effects of Workload and Work Environment Against Non Physical Performance With Burnout As an intervening variable, Abstract, available athttp://repository.umy.ac.id/handle/123456789/ 12877

Rizky, Denizia., And Wulida, Tri Afrianty., (2018), The Effects Of Stress Workload Work With Work 
Life Balance As an intervening variable (Studies in Social Service Surabaya East Java Province), Journal of Business Administration (JAB) | Vol. 61 No. August 4th, 2018 । administrasibisnis.studentjournal.ub.ac.id, Pages 47-53, Faculty of Administration, Universitas Brawijaya, Malang.

Sedarmayanti, (2013). Good govermance (Good Governance) in the Context of Regional Autonomy. Mandar Maju: Bandung.

Sugiyono, 2014. Business Research Methods .: Alfabeta, Bandung

Sunyoto, AM (2011). Industrial and Organizational Psychology. University of Indonesia (UI-Press), Jakarta.

Susilo, AB et al. (2012). Problem Based Learning Model to Improve Science Learning Motivation and Critical Thinking Ability Students. Unnes Science Education Journal.USEJ 1 (1) Available online: http: // Junior journal.unnes.ac.id/sju/index.php/usej/article/do wnload $/ 318 / 367$

(July 23 2012).

Tarwaka, Solichul HB, Lilik S, (2015). Ergonomics for Occupational Safety and Productivity. Surakarta: UNIBA Press.

Law No. 44 Year 2009 on Hospitals. Jakarta 2009. 